\title{
Past physical activity and its influence on female functioning during perimenopause
}

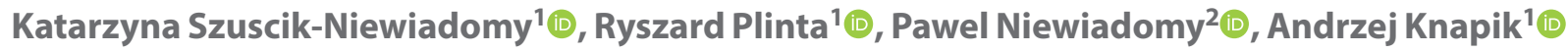 \\ ${ }^{1}$ Department of Adapted Physical Activity and Sport, School of Health Sciences in Katowice, \\ Medical University of Silesia in Katowice, Poland \\ ${ }^{2}$ Department of Balneoclimatology and Biological Regeneration, School of Health Sciences in Katowice, \\ Medical University of Silesia in Katowice, Poland
}

\begin{abstract}
Objectives: The objective of the study was to assess correlations between practising sports at an elite level at a young age, and the current physical activity level, selected sociometric features and the severity of menopausal symptoms in women during perimenopause, which will contribute to the knowledge about undertaking sports activity.

Material and methods: The study involved a total of 334 females aged 45-65. They were purposefully assigned to both a study and control group. The study group included 148 women — former elite athletes qualified based on the presumed criteria. The control group consisted of 154 women who did not meet the criterion of practising sports activity earlier in life. In order to conduct the study, we applied the method of a diagnostic survey. The outcome measure was a survey questionnaire and contained questions concerning sociometric features, some elements of gynaecological history, and physical activity undertaken in the past. The second part used the International Physical Activity Questionnaire (IPAQ) and Blatt-Kupperman Menopausal Index.

Results: The groups were homogenous in terms of age and BMI. The former athletes most frequently used to practise athletics, team games and swimming. Both groups displayed no differences regarding the age at menarche, the onset of sexual activity, and the presence and regularity of menstruation. The former athletes had fewer children compared to the controls. They manifested a higher level of physical activity in particular areas and intensity categories. The comparison between the two groups did not show statistically significant differences in the severity of menopausal symptoms.

Conclusions: Sports training in the past differentiates selected sociometric features such as economic activity and a numerous pregnancies and births. Sports training in the past has an impact on the current level of physical activity — the females who used to train present its higher level.
\end{abstract}

Sports training in the past does not differentiate the severity of menopausal symptoms.

Key words: physical activity; sports; menopause; healthy lifestyle

Ginekologia Polska 2021; 92, 5: 352-358

\section{INTRODUCTION}

Perimenopause is the time in a woman's life where the effects of oestrogen deficiency are mostly noticeable, ranging from vasomotor symptoms, metabolic syndrome and mood changes to urogenital disorders with the symptoms of vaginal atrophy and wasting. There are many factors that determine the age of the occurrence of menopause /the last menstrual period/ such as genetic and environmental factors, ovarian surgeries, taking stimulants, obesity and, indirectly, physical inactivity [1-4].

Physical effort regulates changes at the level of hormone metabolism and thus affects the regularity of the menstru- al cycle, governed by the hypothalamic-pituitary-ovarian axis $[5,6]$.

As shown by research, high intensity physical effort of females during puberty may lead to an adverse syndrome referred to as the Female Athlete Triad (FAT) [7, 8]. It includes eating disorders combined with a low energy level, hormonal imbalances and the occurrence of osteopenia or osteoporosis. This phenomenon was first described more than 20 years ago by Yeager et al. [8]. The athletes could have been qualified to the triad group in the 1990s are between 40 and 50 presently, and only now is it possible to assess long-term effects of potential disorders.

\author{
Corresponding author: \\ Katarzyna Szuscik-Niewiadomy \\ Department of Adapted Physical Activity and Sport, School of Health Sciences in Katowice, Medical University of Silesia in Katowice, 8 Medyków St, 40-752 Katowice, Poland \\ e-mail: kszuscik@sum.edu.pl
}


Menopause occurs later (after the age of 50) in the women who have had many children, live a healthy lifestyle and are free of addictions [9-12].

Numerous studies have attempted to evaluate the effect of physical activity on the timing and course of menopause. It has been noted that the occurrence of menopause may be delayed in those who are physically active. However, there has been no explicit research concerning the impact of high intensity physical activity or long-term observation of its effects. Moreover, many authors indicate the necessity of further investigation into this issue [13-15].

Getting familiar with long-term effects of female sports activity does not only have educational value but also potential for practical application.

\section{Objectives}

The objective of the study was to assess correlations between practising sports at the elite level at young age, and the current physical activity level, selected sociometric features and the severity of menopausal symptoms in women during perimenopause, which will contribute to the knowledge about undertaking sports activity.

\section{MATERIAL AND METHODS}

The study involved a total of 334 females aged 45-65 . They were purposefully assigned to both a study and control group. The study group included 148 women - former elite athletes, according to the presumed inclusion criteria: age 45-65, female gender, consent to participate in the study, filling in the survey questionnaire, meeting the criteria of sports activity undertaken in the past (training experience of no less than five years, participation in sports competition of a championship rank on a national or international level, association with a sports club as a competitor, sports training finished at least ten years before the date of participation in the study).

Thecontrolgroupcomprised 154 women whodidnotmeet the presumed criteria concerning sports activity earlier in life.
Thirty-two women were excluded from statistical analysis in view of failing to meet the inclusion criteria or incompletely answering the questions in the survey questionnaire.

Descriptive statistics presenting age, morphological parameters and chosen sociometric features are summarised in Tables 1, 2.

The course of sports career in the study group is characterised in Table 3 . The former athletes most frequently practised athletics $(n=49 ; 33.11 \%)$, team games including volleyball $(n=23 ; 15.54 \%)$, basketball $(n=18 ; 12.16 \%)$ and handball ( $n=14 ; 9.46 \%)$, as well as swimming $(n=14 ; 9.46 \%)$ and other disciplines ( $n=30 ; 20.27 \%)$.

The research project obtained approval no KNW/0022/ /KB/103/14 of the Bioethics Committee of the Medical University of Silesia in Katowice, Poland.

In order to achieve the stated objective of the study, it was necessary to contact individuals from the sports environment. The respondents could receive the questionnaire in two different ways: by e-mail - as a Word document, or in person - receiving a copy of the questionnaire and an addressed envelope during a meeting. Having filled in the questionnaire the participants returned it by e-mail or by post. We collected $33 \%$ out of approximately 1000 questionnaires distributed.

In the study we applied the method of a diagnostic survey. The outcome measure was a survey questionnaire, filled in anonymously. This included our own part which contained questions concerning sociometric features (namely age, place of residence, marital status, economic activity, as well as body height and weight, based on which the body mass index (BMI) was calculated), and selected elements of gynaecological history. This part also contained questions characterising the type and character of the sports activity undertaken in the past.

The following part of the questionnaire consisted in the International Physical Activity Questionnaire (IPAQ). In accordance with the existing definition of physical activity, described as "each body movement provoked by work

\begin{tabular}{|c|c|c|c|c|c|c|c|c|}
\hline Variable & Group & $n$ & $x$ & Me & Min & Max & SD & $p^{1}$ \\
\hline \multirow{2}{*}{$\begin{array}{l}\text { Age } \\
\text { (years) }\end{array}$} & Study & 148 & 51.33 & 50.00 & 45.00 & 65.00 & 5.58 & \multirow{2}{*}{0.2173} \\
\hline & Controls & 154 & 51.72 & 51.50 & 45.00 & 64.00 & 4.71 & \\
\hline \multirow{2}{*}{$\begin{array}{l}\text { Body mass } \\
{[\mathrm{kg}]}\end{array}$} & Study & 148 & 68.74 & 68.50 & 50.00 & 98.00 & 9.20 & \multirow{2}{*}{0.4063} \\
\hline & Controls & 154 & 70.33 & 69.50 & 49.00 & 108.00 & 11.70 & \\
\hline \multirow{2}{*}{$\begin{array}{l}\text { Body height } \\
\text { [m] }\end{array}$} & Study & 148 & 1.68 & 1.68 & 1.52 & 1.84 & 0.06 & \multirow{2}{*}{0.0000} \\
\hline & Controls & 154 & 1.64 & 1.64 & 1.50 & 1.87 & 0.06 & \\
\hline \multirow{2}{*}{$\begin{array}{l}\mathrm{BMI} \\
{\left[\mathrm{kg} / \mathrm{m}^{2}\right]}\end{array}$} & Study & 148 & 24.29 & 23.74 & 18.37 & 33.20 & 3.01 & \multirow{2}{*}{0.0000} \\
\hline & Controls & 154 & 26.06 & 25.25 & 18.37 & 40.15 & 4.15 & \\
\hline
\end{tabular}

${ }^{1}$ Analysis of variance ANOVA 


\begin{tabular}{|c|c|c|c|c|c|c|c|}
\hline \multirow{2}{*}{\multicolumn{2}{|c|}{ Variable }} & \multicolumn{2}{|c|}{ Study group } & \multicolumn{2}{|c|}{ Control group } & \multirow{2}{*}{$\mathrm{Chi}^{2}$} & \multirow{2}{*}{$\mathbf{p}^{1}$} \\
\hline & & \multirow{2}{*}{$\begin{array}{c}\mathbf{n}=\mathbf{1 4 8} \\
126\end{array}$} & \multirow{2}{*}{$\begin{array}{c}\% \\
85.14\end{array}$} & \multirow{2}{*}{$\begin{array}{c}\mathbf{n}=154 \\
121\end{array}$} & \multirow{2}{*}{\begin{tabular}{c|}
$\%$ \\
78.57 \\
\end{tabular}} & & \\
\hline Place of recidence & City/town & & & & & 210 & 01305 \\
\hline riace on manemice & Country & 22 & 14.86 & 33 & 21.43 & 2.10 & נצכון \\
\hline \multirow{3}{*}{ Marital status } & Single & 23 & 15.54 & 9 & 5.84 & \multirow{3}{*}{8.19} & \multirow{3}{*}{0.8474} \\
\hline & Spouse/partner & 114 & 7.03 & 133 & 86.37 & & \\
\hline & Divorced/separated/widow & 11 & 7.43 & 12 & 7.79 & & \\
\hline \multirow{3}{*}{ Education } & Primary and vocational & 10 & 6.75 & 10 & 6.49 & \multirow{3}{*}{13.39} & \multirow{3}{*}{0.0038} \\
\hline & Secondary & 24 & 16.22 & 53 & 34.42 & & \\
\hline & University/college & 114 & 77.03 & 91 & 59.09 & & \\
\hline \multirow{2}{*}{ Current economic activity } & Economically active & 132 & 89.19 & 127 & 82.47 & \multirow{2}{*}{9.02} & \multirow{2}{*}{0.0110} \\
\hline & Inactive & 16 & 10.81 & 27 & 17.53 & & \\
\hline \multirow{2}{*}{$\begin{array}{l}\text { Economic activity connected } \\
\text { with sports }\end{array}$} & Yes & 78 & 52.70 & 9 & 5.84 & \multirow{2}{*}{80.80} & \multirow{2}{*}{0.0000} \\
\hline & No & 70 & 47.30 & 145 & 94.16 & & \\
\hline
\end{tabular}

${ }^{1}$ Chi ${ }^{2}$ test

\begin{tabular}{|c|c|c|c|c|c|}
\hline Variable & $\mathbf{X}$ & Me & Min & Max & SD \\
\hline $\begin{array}{l}\text { Age when training } \\
\text { started (years) }\end{array}$ & 11.66 & 12.00 & 3.00 & 27.00 & 3.17 \\
\hline $\begin{array}{l}\text { Age when training } \\
\text { finished (years) }\end{array}$ & 22.20 & 22.00 & 12.00 & 39.00 & 5.21 \\
\hline $\begin{array}{l}\text { Training experience } \\
\text { (years) }\end{array}$ & 10.55 & 9.00 & 5.00 & 27.00 & 5.14 \\
\hline $\begin{array}{l}\text { Time that has } \\
\text { passed since the } \\
\text { sports career } \\
\text { ended (years) }\end{array}$ & 29.05 & 29.00 & 10.00 & 49.00 & 6.63 \\
\hline
\end{tabular}

of the skeletal muscles which requires energy expenditure exceeding the value at rest" [16], the tool allows weekly energy expenditure to be calculated and expressed in MET-minutes/week (Metabolic Equivalent of Work). This unit is the product of a MET index value ascribed to each type of physical activity, the number of days during which particular activity was performed, and duration of the activity in minutes per day (according to the instruction of the outcome calculation protocol). The value of MET-minutes/week constitutes the total capacity of the activity on a daily and weekly basis.

The application of a long IPAQ version enabled us to estimate the levels of physical activity for five areas: locomotion, economic activity, housework and cleaning, leisure time and spending time in a sitting position $[17,18]$.

In order to assess the severity of menopausal symptoms we used the Blatt-Kupperman Menopausal Index, which determines the severity of eleven characteristic symptoms based on a four-point scale from zero points (for the ab- sence of symptoms) to three points (severe symptoms). The total sum of points was interpreted as follows: absence of symptoms: $0-5$ points, mild degree: 6-10 points, moderate degree: $11-15$ points, and severe degree $>15$ points $[5,19]$.

Statistical analysis was performed based on the Statistica 13.3 program (by STATSOFT). In descriptive statistics for qualitative variables, the findings were presented together with the group sizes ( $n$ ) and percentage values (\%), considering the lack of data in some cases. The outcomes concerning quantitative variables were presented in the form of measures of location, that is, arithmetic mean ( $\mathrm{x}$ ), median (Me), and measures of variability, namely standard deviation (SD). In addition, minimum (min) and maximum (max) values were provided. In order to establish whether the variables were normally distributed regarding the group size, the Shapiro-Wilk test was applied. In the case of quantitative variables, the analysis of variance ANOVA and the Mann-Whitney $U$ test were used for determining the level of differences between the groups, and the Pearson correlation coefficient - for checking correlations between the variables. Nonparametric statistics (Chi ${ }^{2}$ test) were used for the qualitative variables. The level of statistical significance was established at $a=0.05$, providing the test probability value $p$.

\section{RESULTS}

The answers to chosen questions characterising the obstetric and gynaecological profiles of the women are summarised in Tables 4-7.

We have not found significant differences in the age at menarche, the onset of sexual activity, as well as presence and regularity of menstruation between the groups (Tab. 4, 6).

Moreover, the study group got divided into the individuals whohad started training beforethefirstmenstruation (group 1) 


\begin{tabular}{|c|c|c|c|c|c|c|c|c|}
\hline Variable & Group & n & $x$ & Me & Min & Max & SD & $\mathbf{p}^{1}$ \\
\hline \multirow{2}{*}{ Age at menarche [years] } & Study & 148 & 13.32 & 13.00 & 10.00 & 18.00 & 1.70 & \multirow{2}{*}{0.8478} \\
\hline & Controls & 154 & 13.29 & 13.00 & 10.00 & 17.00 & 1.45 & \\
\hline \multirow{2}{*}{ Age of sexual activity onset [years] } & Study & 148 & 20.24 & 20.00 & 14.00 & 26.00 & 2.01 & \multirow{2}{*}{0.4583} \\
\hline & Controls & 154 & 20.42 & 20.00 & 16.00 & 28.00 & 2.22 & \\
\hline
\end{tabular}

${ }^{1}$ Analysis of variance ANOVA

Table 5. The age at menarche in the study group: the individuals starting training before and after menarche

\begin{tabular}{|l|l|l|l|l|l|l|l|l|}
\hline Variable & Group & $\mathbf{n}$ & $\mathbf{x}$ & Me & Min & Max & SD & $\mathbf{p}^{\mathbf{1}}$ \\
\hline \multirow{2}{*}{ Age at menarche [years] } & Group 1 & 89 & 13.90 & 14.00 & 10.00 & 18.00 & 1.69 & 0.0000 \\
\hline & Group 2 & 59 & 12.49 & 12.00 & 10.00 & 16.00 & 1.31 & 0.00 \\
\hline
\end{tabular}

Group 1 - the females who started training before menarche; group 2 - the females who started training after menarche; ${ }^{1}$ Mann-Withey $\mathrm{U}$ test

\begin{tabular}{|c|c|c|c|c|c|c|c|}
\hline \multirow{2}{*}{\multicolumn{2}{|c|}{ Menstruation }} & \multicolumn{2}{|c|}{ Study group } & \multicolumn{2}{|c|}{ Control group } & \multirow{2}{*}{ Chi2 } & \multirow{2}{*}{$\mathbf{p}^{1}$} \\
\hline & & $n=148$ & $\%$ & $n=154$ & $\%$ & & \\
\hline \multirow{2}{*}{ Presence } & Yes & 84 & 56.76 & 77 & 50.00 & \multirow{2}{*}{1.38} & \multirow{2}{*}{0.2394} \\
\hline & No & 64 & 43.24 & 77 & 50.00 & & \\
\hline \multirow{3}{*}{ Regularity } & Yes & 70 & 47.30 & 66 & 42.86 & \multirow{3}{*}{0.44} & \multirow{3}{*}{0.5067} \\
\hline & No & 13 & 8.78 & 9 & 5.84 & & \\
\hline & No data & 65 & 43.92 & 79 & 51.30 & & \\
\hline
\end{tabular}

${ }^{1}$ Chi ${ }^{2}$ test

and the ones who experienced their menarche during the sports career (group 2). A statistically significant difference has been noted between these two groups as for the age at menarche (Tab. 5).

The former athletes have had fewer children compared to the control group, and the difference was statistically significant (Tab. 7).

Comparing both the study and control groups has not revealed statistically significant differences in the severity of menopausal symptoms (Tables 8-10).

Tables 11 and 12 present the findings of the IPAQ questionnaire. The former athletes demonstrated higher levels of physical activity in particular areas and intensity categories. These differences proved statistically significant. In accordance with the suggested IPAQ methodology and considering the size of the groups, the persons with low level physical activity were joined with those with moderate level activity, forming one category. The individuals presenting high level activity constituted the other group (Table 12).

Moreover, the study group has displayed only a weak positive correlation between age and the severity of menopausal symptoms $(r=0.236, p=0.004)$, and between the duration of time that has passed since the end of the sports career [in years] and the deterioration of menopausal symptoms $(r=0.209, p=0.011)$. A negative correlation has also been noted between training experience [in years] and a general level of physical activity $(r=-0.188, p=0.022)$.

\section{DISCUSSION}

Pubertal maturation and menstrual cycle are modified by sports activity, a phenomenon confirmed in many publications [20-23]. Low proportion of adipose tissue, inappropriate diet and malnutrition relate to the delayed puberty and later menarche $[24,25]$. In the present study, the age at the first menstruation was 13.3 years and in this respect, there was no statistically significant difference between the study and control groups. This age reflects the average age at menarche as determined for the European population [26]. The same value was noted in other studies of young female athletes, conducted among others by Czajkowska et al. [20] and Skierska [27]. When analysing possible causes of the lack of the difference between the groups, it is worth drawing attention to sports disciplines practised by the respondents in the past (in a vast majority of cases it was athletics, team games and swimming). Low numbers of the 


\begin{tabular}{|c|c|c|c|c|c|c|}
\hline \multirow{2}{*}{\multicolumn{2}{|c|}{ Variable }} & \multicolumn{2}{|c|}{ Study group } & \multicolumn{2}{|c|}{ Control group } & \multirow{2}{*}{$\mathbf{p}^{1}$} \\
\hline & & $n=148$ & $\%$ & $n=154$ & $\%$ & \\
\hline \multirow{4}{*}{ Number of pregnancies } & 0 & 31 & 20.95 & 14 & 9.09 & \multirow{4}{*}{0.0014} \\
\hline & 1 & 26 & 17.57 & 28 & 18.18 & \\
\hline & 2 & 67 & 45.27 & 68 & 44.16 & \\
\hline & $3 \&$ more & 24 & 16.21 & 44 & 28.57 & \\
\hline \multirow{4}{*}{ Number of births } & 0 & 34 & 22.97 & 15 & 9.74 & \multirow{4}{*}{0.0009} \\
\hline & 1 & 31 & 20.95 & 30 & 19.48 & \\
\hline & 2 & 70 & 47.30 & 82 & 53.25 & \\
\hline & $3 \&$ more & 13 & 8.78 & 27 & 17.53 & \\
\hline
\end{tabular}

${ }^{1}$ Analysis of variance ANOVA

\begin{tabular}{l|l|c|c|c|c|c|c|c|c|}
\hline \multicolumn{1}{l}{ Table 8. Descriptive statistics of the Blatt-Kupperman Menopausal Index findings } \\
\hline Variable & Group & $\mathbf{n}$ & $\mathbf{x}$ & Me & Min & Max & SD \\
\hline \multirow{2}{*}{ Blatt-Kupperman index } & Study & 148 & 10.45 & 8.00 & 0.00 & 38.00 & 8.19 \\
\hline & Controls & 154 & 10.93 & 9.00 & 0.00 & 37.00 & 8.75 \\
\hline
\end{tabular}

${ }^{1}$ Analysis of variance ANOVA

Table 9. Presence of menopausal symptoms based on the Blatt-Kupperman index - categories

\begin{tabular}{|c|c|c|c|c|c|c|}
\hline \multirow{2}{*}{ Severity of menopausal symptoms } & \multicolumn{2}{|c|}{ Study group } & \multicolumn{2}{|c|}{ Control group } & \multirow{2}{*}{ Chi-square } & \multirow{2}{*}{$\mathbf{p}^{1}$} \\
\hline & $n=148$ & $\%$ & $n=154$ & $\%$ & & \\
\hline Absence of symptoms & 54 & 36.49 & 51 & 33.12 & \multirow{4}{*}{3.21} & \multirow{4}{*}{0.3601} \\
\hline Mild symptoms & 30 & 20.27 & 37 & 24.03 & & \\
\hline Moderate symptoms & 30 & 20.27 & 22 & 14.29 & & \\
\hline Severe symptoms & 34 & 22.97 & 44 & 28.56 & & \\
\hline
\end{tabular}

${ }^{1} \mathrm{Chi}{ }^{2}$ test

Table 10. Severity of menopausal symptoms in menstruating and non-menstruating women from the study group

\begin{tabular}{|l|c|c|c|c|c|c|c|c|c|}
\hline Variable & Group & $\mathbf{n}$ & $\mathbf{x}$ & Me & Min & Max & SD & $\mathbf{p}^{1}$ \\
\hline \multirow{2}{*}{ Severity of menopausal symptoms } & M & 84 & 8.12 & 6.00 & 0.00 & 38.00 & 7.40 & 0 \\
\cline { 1 - 8 } & NM & 64 & 13.52 & 12.50 & 0.00 & 33.00 & 8.24 & 0.0000 \\
\hline
\end{tabular}

The division of women into 2 groups: $\mathrm{M}$ - menstruating; $\mathrm{NM}$ - non-menstruating — this refers to the women who have not had menstrual bleeding for at least 12 months; ${ }^{1}$ Mann-Withney U test

females training particular disciplines restricted the possibility of assessing each of them separately. According to Malina et al. [20] and Skierska et al. [21], training certain sport disciplines is related to the delay in pubertal maturation in females. This concerns for instance gymnastics, basketball, volleyball and swimming. In the remaining disciplines the menarche age corresponds to the norms for the population, or is slightly lower, which results from the high pace of pubertal maturation. It is observed in such disciplines as judo, handball or football. However, faster pubertal maturation in consequence of physical training is characteristic for males.
No publications have been found presenting the quantitative characteristics of childbirths in a population of former female athletes. Our study has demonstrated a statistically significant difference in the number of pregnancies and births between the females practising sports and the control group, which is a novelty in the light of the so far conducted research. Comparing to the control group, the former athletes more often had no offspring at all or statistically fewer children. There can be a range of explanations of this difference, starting with the above-mentioned FAT syndrome [7, 8], through the commitment to a sports career as a priority at 


\begin{tabular}{|c|c|c|c|c|c|c|c|c|c|}
\hline $\begin{array}{l}\text { Domains of physical } \\
\text { activity }\end{array}$ & Group & $\mathbf{x}$ & Me & Min & Max & $\mathbf{Q}_{1}$ & $Q_{3}$ & SD & $\mathbf{p}^{1}$ \\
\hline \multirow{2}{*}{ Economic activity } & $S$ & 3973.5 & 3165 & 0 & 1377 & 946.5 & 6433 & 3594 & \multirow{2}{*}{0.0001} \\
\hline & C & 2421.5 & 1200 & 0 & 14364 & 0 & 3976 & 3029.7 & \\
\hline \multirow{2}{*}{ Locomotion } & $S$ & 1679.9 & 1039.5 & 0 & 6858 & 558 & 2254.5 & 1594 & \multirow{2}{*}{0.5163} \\
\hline & C & 1802.3 & 1188 & 0 & 7758 & 396 & 2799 & 1676.4 & \\
\hline \multirow{2}{*}{ Housework, cleaning } & $S$ & 2337.2 & 1335 & 0 & 14310 & 750 & 3135 & 2365.8 & \multirow{2}{*}{0.2130} \\
\hline & C & 2715.4 & 1750 & 0 & 14595 & 670 & 3780 & 2866.5 & \\
\hline \multirow{2}{*}{ Leisure time } & $\mathrm{S}$ & 1659.6 & 1161.8 & 0 & 11118 & 590.3 & 2088 & 1783.1 & \multirow{2}{*}{0.0122} \\
\hline & C & 1176.5 & 594 & 0 & 7128 & 198 & 1470 & 1586.4 & \\
\hline \multirow{2}{*}{$\begin{array}{l}\text { Time spent in a sitting } \\
\text { position }\end{array}$} & $S$ & 1654.3 & 1470 & 0 & 5400 & 960 & 2280 & 958.2 & \multirow{2}{*}{0.0102} \\
\hline & C & 2046.4 & 1740 & 0 & 7200 & 1170 & 2700 & 1286.6 & \\
\hline \multirow{2}{*}{$\begin{array}{l}\text { General level of } \\
\text { physical activity }\end{array}$} & $S$ & 9650.1 & 8781 & 1650 & 30180 & 5637.7 & 4862.8 & 13519.5 & \multirow{2}{*}{0.0217} \\
\hline & C & 8115.8 & 6801 & 498 & 31242 & 5909.2 & 3970.5 & 10668 & \\
\hline
\end{tabular}

Groups: S - study; C - controls; ${ }^{1}$ Analysis of variance ANOVA

\begin{tabular}{|c|c|c|c|c|c|c|c|}
\hline \multirow{2}{*}{\multicolumn{2}{|c|}{ Categories of physical activity }} & \multicolumn{2}{|c|}{ Study group } & \multicolumn{2}{|c|}{ Control group } & \multirow{2}{*}{ Chi-square } & \multirow{2}{*}{$\mathbf{p}^{1}$} \\
\hline & & $n=148$ & $\%$ & $n=154$ & $\%$ & & \\
\hline \multirow{2}{*}{ Physical activity level } & Low and moderate & 107 & 72.30 & 127 & 82.47 & \multirow{2}{*}{7.87} & \multirow{2}{*}{0.0339} \\
\hline & High & 41 & 27.70 & 27 & 17.53 & & \\
\hline
\end{tabular}

${ }^{1}$ Chi' ${ }^{2}$ test

the life stage most conducive to having a child, and finishing with concerns about changing the body image during pregnancy (where the body is sometimes considered a model), and losing certain control over it $[28,29]$. Other causes also include loss of physical ability during pregnancy and thus fear of the return to full physical fitness, required in elite sports. An equally important problem is the economic situation of athletes, including maintaining grants or sponsorship irrespective of the absence [30,31].

In the literature, there is a great deal of evidence that an active lifestyle is a factor that has beneficial effects on the process of ageing, while physical activity, which is one of its elements, brings more positive than negative consequences. This can be a starting point for considerations of the correlations between sports activity and age as well as the course of menopause. According to a publication by Serra et al. [32], the women participating in sports competition experience ageing positively, which may also be true about smoothly undergoing perimenopause. The researchers also demonstrate the benefits resulting from sports competition compared to the women presenting a sedentary lifestyle, including a higher level of maximal aerobic capacity ( $\mathrm{VO}^{2} \mathrm{max}$ ), more beneficial body composition (lower proportion of adipose tissue, higher muscle mass) and a better lipid profile at an older age. To a certain extent, those observations have been confirmed by the BMI comparison performed in our study. However, no publications have been found that show direct dependencies between the age when menopause occurs and training sports before.

The former athletes presented the level of physical activity that was statistically significantly higher as well as higher physical activity in particular domains compared to the control group. Higher results in the domain physical activity connected with economic activity should be explained, among others, by the character of their professional career. More than $50 \%$ of the women had jobs connected with sports; they worked as physical education teachers. It must be assumed that this kind of work is related to a higher-than-average activity level by its definition. The fact of continuing activity in sport-related areas after finishing the career as an athlete is something that is natural and frequently observed.

\section{CONCLUSIONS}

Sports training in the past differentiates selected sociometric features such as economic activity and a numerous pregnancies and births.

Sports training in the past has an impact on the current level of physical activity - the females who used to train present its higher level. 
Sports training in the past does not differentiate the severity of menopausal symptoms.

\section{Conflict of interests}

The authors declare that they have no conflict of interests.

\section{Funding}

The project was financed from the agreement to conduct research no KNW-2-065/D/5/N by the Medical University of Silesia in Katowice, Poland.

\section{REFERENCES}

1. Stetkiewicz T. Badania nad menopauzą w latach 90-tych. WHO 1996. Instytut Medycyny Pracy im.Prof J Nofera, Łódź 2001.

2. Paszkowski T. Postępy w medycynie menopauzy. IZT, Lublin 2009.

3. WHO. Quality of life assessment: Position paper from the World health organization. Soc Sci Med. 1995; 41(10): 1403-1409.

4. Stepaniak U, Szafraniec K, Kubinova R, et al. Age at natural menopause in three central and eastern European urban populations: the HAPIEE study. Maturitas. 2013; 75(1): 87-93, doi: 10.1016/j.maturitas.2013.02.008, indexed in Pubmed: 23489553.

5. Skałba P. Endokrynologia ginekologiczna. PZWL, Warszawa 2008.

6. Mędraś M, Jóźków P. Aktywność fizyczna a oś podwzgórze — przysadka — jajniki - endokrynologiczne aspekty zespołu triady sportsmenek. In: Mędraś M. ed. Endokrynologia wysiłku fizycznego sportowców z zarysem endokrynologii ogólnej. Medpharm Polska, Wrocław 2010: 136-147.

7. Torstveit MK, Sundgot-Borgen J. The female athlete triad exists in both elite athletes and controls. Med Sci Sports Exerc. 2005; 37(9): 1449-1459, doi: 10.1249/01.mss.0000177678.73041.38, indexed in Pubmed: 16177594.

8. Nattiv A, Agostini R, Drinkwater B, et al. The female athlete triad: disordered eating, amenorrhea, osteoporosis. Med Sci Sports Exerc. 1993; 25(7): 775-777, doi: 10.1249/00005768-199307000-00003, indexed in Pubmed: 8350697.

9. Kaczmarek M. The timing of natural menopause in Poland and associated factors. Maturitas. 2007; 57(2): 139-153, doi: 10.1016/j.maturitas.2006.12.001, indexed in Pubmed: 17307314.

10. Ortiz AP, Harlow SD, Sowers M, et al. Age at natural menopause and factors associated with menopause state among Puerto Rican women aged 40-59 years, living in Puerto Rico. Menopause. 2006; 13(1): 116-124, doi: 10.1097/01.gme.0000191207.28362.22, indexed in Pubmed: 16607107.

11. Parazzini F. Determinants of age at menopause in Italy: results from a large cross-sectional study. Maturitas. 2007; 56: 280-287, doi: 10.1016/j. maturitas.2006.09.003.

12. Nagel G, Altenburg HP, Nieters A, et al. Reproductive and dietary determinants of the age at menopause in EPIC-Heidelberg. Maturitas. 2005; 52(3-4): 337-347, doi: 10.1016/j.maturitas.2005.05.013, indexed in Pubmed: 16011884.

13. McTiernan A, Tworoger S, Ulrich C. Effect of exercise on serum estrogens in postmenopausal women: a 12-month randomized clinical trial. Cancer Res. 2004; 64(8): 2923-2928, doi: 10.1158/0008-5472.can-03-3393, indexed in Pubmed: 15087413.

14. Dąbrowska J, Naworska B, Dąbrowska-Galas M, et al. The role of physical activity in menopause. Menopausal Review. 2012; 6: 445-448, doi: 10.5114/pm.2012.32535.

15. Friedenreich $\mathrm{CM}$, Neilson $\mathrm{HK}$, Wang Q, et al. Effects of exercise dose on endogenous estrogens in postmenopausal women: a randomized trial.
Endocr Relat Cancer. 2015; 22(5): 863-876, doi: 10.1530/ERC-15-0243, indexed in Pubmed: 26338699.

16. Caspersen CJ, Powell KE, Christenson GM. Physical activity, exercise, and physical fitness: definitions and distinctions for health-related research. Public Health Rep. 1985; 100(2): 126-131, indexed in Pubmed: 3920711.

17. The IPAQ Group. Guidelines for Data Processing and Analysis of the International Physical Activity Questionnaire (IPAQ) - Short and Long Forms. 2005. http://www.ipaq.ki.se.

18. Biernat E, Stupnicki R, Gajewski A. International Physical Activity Questionarie (IPAQ) - Polish version. Wych fiz i Sport. 2007; 1: 47-54.

19. Alder E. The Blatt-Kupperman menopausal index: a critique. Maturitas. 1998; 29(1): 19-24, doi: 10.1016/s0378-5122(98)00024-3, indexed in Pubmed: 9643513.

20. Skierska E. Age at menarche and prevalence of oligo/amenorrhea in top Polish athletes. Am J Hum Biol. 1998; 10(4): 511-517, doi: 10.1002/ (SICI)1520-6300(1998)10:4<511::AID-AJHB11>3.0.CO;2-B, indexed in Pubmed: 28561474.

21. Malina RM, Rogol AD, Cumming SP, et al. Biological maturation of youth athletes: assessment and implications. Br J Sports Med. 2015; 49(13): 852-859, doi: 10.1136/bjsports-2015-094623, indexed in Pubmed: 26084525.

22. Myburgh GK, Cumming SP, Silva MC, et al. Maturity-associated variation in functional characteristics of elite youth tennis players. Pediatr Exerc Sci. 2016; 28(4): 542-552, doi: 10.1123/pes.2016-0035, indexed in Pubmed: 27295031.

23. Matina RM, Rogol AD. Sport training and the growth and pubertal maturation of young athletes. Pediatr Endocrinol Rev. 2011; 9(1): 441-455, indexed in Pubmed: 22783642.

24. Bacchi E, Spiazzi G, Zendrini G, et al. Low body weight and menstrual dysfunction are common findings in both elite and amateur ballet dancers. J Endocrinol Invest. 2013; 36(5): 343-346, doi: 10.3275/8645, indexed in Pubmed: 23027765.

25. Doyle-Lucas AF, Akers JD, Davy BM. Energetic efficiency, menstrual irregularity, and bone mineral density in elite professional female ballet dancers. J Dance Med Sci. 2010; 14(4): 146-154, indexed in Pubmed: 21703085.

26. Malina R. Secular trends in growth, maturation and physical performance: A review. Anthropol Rev. 2004(67): 3-31.

27. Czajkowska M, Drosdzol-Cop A, Gałązka I, et al. Menstrual Cycle and the Prevalence of Premenstrual Syndrome/Premenstrual Dysphoric Disorder in Adolescent Athletes. J Pediatr Adolesc Gynecol. 2015; 28(6): 492-498, doi: 10.1016/j.jpag.2015.02.113, indexed in Pubmed: 26233292.

28. Rice SM, Purcell R, De Silva S, et al. The Mental Health of Elite Athletes: A Narrative Systematic Review. Sports Med. 2016; 46(9): 1333-1353, doi: 10.1007/s40279-016-0492-2, indexed in Pubmed: 26896951.

29. Giannone ZA, Haney CJ, Kealy D, et al. Athletic identity and psychiatric symptoms following retirement from varsity sports. Int J Soc Psychiatry. 2017; 63(7): 598-601, doi: 10.1177/0020764017724184, indexed in Pubmed: 28795636.

30. Martínez-Pascual B, Alvarez-Harris S, Fernández-de-Las-Peñas C, et al. Pregnancy in Spanish elite sportswomen: A qualitative study. Women Health. 2016; 20: 1-15.

31. Hodgkinson EL, Smith DM, Wittkowski A. Women's experiences of their pregnancy and postpartum body image: a systematic review and meta-synthesis. BMC Pregnancy Childbirth. 2014; 14: 330, doi: 10.1186/1471-2393-14-330, indexed in Pubmed: 25248649.

32. Serra M, McMillin S, Ryan A. Aging in women athletes. In: Zaslav KR, McMillin S, Ryan A. ed. An international perspective on topics in sports medicine and sports injury. IntechOpen Limited, London 2012: 3318-4253. 